\section{Gategory}

Organo- and Biocatalysis

\section{Key words}

dynamic kinetic

resolution

polypeptides

biaryls

electrophilic

aromatic

substitution

J. L. GUSTAFSON, D. LIM, S. J. MILLER* (YALE UNIVERSITY, NEW HAVEN, USA)

Dynamic Kinetic Resolution of Biaryl Atropisomers via Peptide-Catalyzed Asymmetric Bromination Science 2010, 328, 1251-1255.

\title{
Dynamic Kinetic Resolution of Axially Chiral Biaryls by Asymmetric Bromination
}

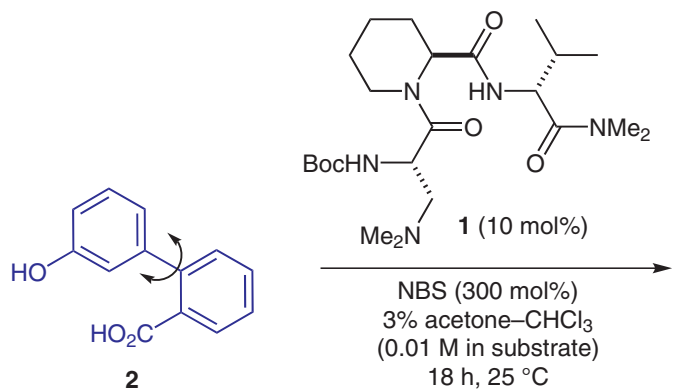

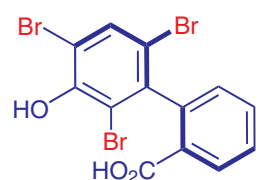

3

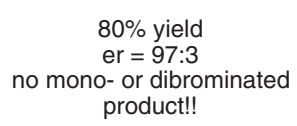

Plausible substrate-catalyst docking model:

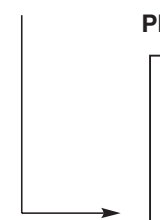

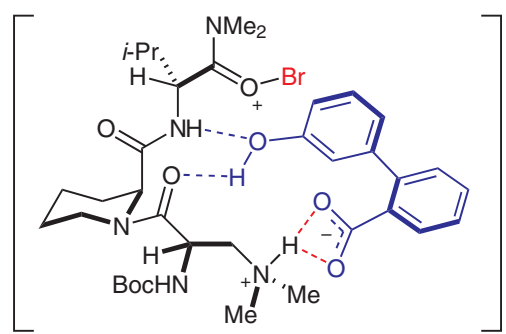

Selected examples:<smiles>O=C([O-])c1cc([N+](=O)[O-])ccc1-c1c(Br)cc(Br)c(O)c1Br</smiles>

$85 \%$ yield, er $=97: 3$<smiles>COc1ccc(-c2c(Br)cc(Br)c(O)c2Br)c(C(=O)O)c1</smiles>

$80 \%$ yield, er $=94: 6$<smiles>O=C(O)c1c(Br)ccc(F)c1-c1c(Br)cc(Br)c(O)c1O</smiles>

$70 \%$ yield, er $=97: 3$<smiles>O=C(O)c1c(Br)c(-c2ccccc2)n([18OH])c1-c1c(Br)cc(Br)c(O)c1Br</smiles>

$70 \%$ yield, er $=95: 5$
Significance: Axially chiral biaryl compounds are tremendously important for organic synthesis. Therefore, catalytic and asymmetric approaches toward this compound class are highly demandable. The authors demonstrate that the dynamic kinetic resolution of biaryl compound 2 can be realized by electrophilic aromatic substitution to afford the non-racemic biaryl 3. To explain the stereoselection of the catalysis, the authors suggest a catalyst-substrate complex in which several amide bonds and the tertiary amine in catalyst $\mathbf{1}$ participate via multiple hydrogen-bonding interactions.

SYNFACTS Contributors: Benjamin List, Ji-Woong Lee

Synfacts 2010, 9, 1074-1074 Published online: 23.08.2010 Dol: 10.1055/s-0030-1257966; Reg-No.: B08310SF
Comment: Miller and co-workers report an elegant and original approach for the synthesis of optically active biaryl compounds. High selectivity for the desired product (up to $80 \%$ yield) and enantioselectivity (up to 97:3 er) was achieved using tripeptide catalyst 1. No mono- and dibrominated products were observed. A broad range of substrates are tolerable and include fluorinated as well as heterocyclic compounds. 